\title{
Penguatan Pendidikan Karakter melalui Pelatihan Penggunaan Aplikasi Kindfull-Digital Character Book
}

\author{
Azmi Fitriati ${ }^{\star *}$, Subuh Anggoro², \& Sri Harmianto² \\ ${ }^{1}$ Fakultas Ekonomi dan Bisnis, Universitas Muhammadiyah Purwokerto, Indonesia \\ ${ }^{2}$ Fakultas Keguruan dan IImu Pendidikan, Universitas Muhammadiyah Purwokerto, \\ Indonesia
}

*azmi.fitriati@gmail.com

\begin{abstract}
Kindfull-digital character book is a character monitoring application based-android and website. Its use is an alternative instrument for strengthening character education. This application made the character monitoring process easier, faster and more precise than the manual process. The purposes of this activity are to introduce, develop and provide skills in using the kindfull-digital character book application as an effective and efficient monitoring instrument for student character. The target users were teachers, parents and students. The method were used training, workshops and assistance in the use of information technology. This, results showed that are easy to learn and operate by users and are easily adapted to user needs. Monitoring this digital character through selfassessment, so it emphasizes the honesty of students, parents and teachers. Based on the results of the evaluation, users felt the usefulness and ease of using the application. Teachers and parents can work together in strengthening student character education. Economically, this application can be used repeatedly, by adding the desired character indicator. Teachers are no longer preoccupied with technical activities but can concentrate on strengthening student character.
\end{abstract}

\begin{abstract}
Abstrak Kindfull-digital character book adalah aplikasi pemantauan karakter berbasis android dan website. Penggunaannya menjadi alternatif instrumen penguatan pendidikan karakter. Aplikasi digital ini membuat proses pemantauan karakter menjadi lebih mudah, cepat dan tepat dibandingkan proses manual. Tujuan kegiatan ini adalah mengenalkan, mengembangkan dan memberikan ketrampilan penggunaan aplikasi kindfull-digital character book sebagai instrumen pemantauan karakter siswa yang efektif dan efisien. Sasaran pengguna aplikasi ini adalah guru, orang tua dan siswa. Metode yang digunakan adalah pelatihan, workshop dan pendampingan penggunaan teknologi informasi. Kegiatan ini menghasilkan aplikasi yang mudah dipelajari dan dioperasikan pengguna serta mudah disesuaikan dengan kebutuhan pengguna. Pemantauan karakter digital ini menggunakan self assessment, sehingga sangat menekankan pada kejujuran baik dari siswa, orang tua dan guru. Berdasarkan hasil evaluasi, pengguna merasakan kegunaan dan kemudahan menggunakan aplikasi tersebut. Guru dan orangtua dapat bekerjasama dalam penguatan pendidikan karakter siswa. Secara ekonomis, aplikasi ini dapat digunakan secara berulang, dengan menambahkan indikator karakter yang diinginkan. Guru tidak lagi disibukkan oleh aktivitas teknis, tetapi dapat berkonsentrasi pada upaya penguatan karakter siswa.
\end{abstract}

Keywords: kindful-digital character book; strengthening character education; perceived usefulness; perceived ease of use; use of information technology

\section{9}

\section{○ OPEN ACCESS}

Citation: Fitriati, A., S. Anggoro, \& S. Harmianto. (2021). Penguatan Pendidikan Karakter melalui Pelatihan Penggunaan Aplikasi Kindfull-Digital Character Book. Riau Journal of Empowerment, 4(1), 29-40.

https://doi.org/10.31258/raje.4.1.29-40

Received: 2020-11-25 Revised: 2021-04-13 Accepted: 2021-04-19

Language: Bahasa Indonesia (id)

ISSN 2623-1549 (online), 2654-4520 (print)

(C2021 Azmi Fitriati, Subuh Anggoro, \& Sri Harmianto. Author(s) retain the copyright of article published in this journal, with first publication rights granted to Riau Journal of Empowerment. The article is licenced under Creative Commons Attribution 4.0 International License. This license permits unrestricted use, distribution, and reproduction in any medium, provided the original author and source are credited. 


\section{PENDAHULUAN}

Salah satu bagian gerakan nasional revolusi mental yang digagas pemerintah Indonesia adalah gerakan penguatan pendidikan karakater. Karakter dikembangkan melalui pendidikan, pelatihan sosial dan pengalaman interpersonal (Agboola \& Tsai, 2012; Marini, 2018). Pendidikan di sekolah dasar perlu mengembangkan pendidikan akademik, keterampilan sosial dan karakter positif (Marini, 2018). Keterampilan sosial, dan karakter disiplin serta toleransi akan mempengaruhi hubungan dengan teman sebaya (Jhon et al., 2021; Izzati et al., 2019). Ketrampilan ini berkorelasi dengan masalah perilaku sosial (Marini, 2018; Jhon et al., 2021), integrasi kecerdasan dan karakter (Suyitno et al., 2019; Saputri et al., 2019), serta konsistensi perilaku di rumah dan sekolah (Gunawan et al., 2020).

Pemerintah telah menerbitkan Perpres no.87/2017, mengenai penguatan pendidikan karakter. Perpres ini bertujuan membangun dan membekali siswa sebagai generasi emas Indonesia tahun 2045. Pendidikan karakter dianggap menjadi jawaban atas perubahan sosial dalam struktur masyarakat di Indonesia yang kini menghadapi peningkatan kriminalitas, pergaulan bebas, penggunaan obat terlarang hingga sikap yang bertentangan dengan nilai dalam masyarakat.

Data Komisi Perlindungan Anak Indonesia (KPAI) mencatat, total pengaduan kasus pornografi dan cyber crime yang menjerat anak-anak pada tahun 2014-2018 terus meningkat. Pada tahun 2014 tercatat sebanyak 322 kasus, menjadi 679 kasus pada tahun 2018. Adapun jenis aduan di antaranya anak korban kejahatan seksual online, pelaku kejahatan online, korban pornografi di media sosial, pelaku kepemilikan media pornografi, dan pelaku bullying di media sosial.

Sementara untuk kejahatan cyber yang paling sering diadukan ke KPAI di antaranya, pelaku video pornografi, sexting (chat bermuatan konten pornografi), terlibat dalam grup-grup pornografi. Selain itu, ada juga sextortion, yaitu pacaran online berujung pemerasan, cyber bully, perjudian online, live streaming video dan trafficking serta penipuan online.

Sekolah Dasar Universitas Muhammadiyah Purwokerto (SD UMP) dalam menghadapi era globalisasi dan revolusi digital yang semakin berkembang, senantiasa menyiapkan kurikulum yang menyeimbangkan kemampuan akademik dengan penguatan pendidikan karakter. Gerakan penguatan pendidikan karakter menempatkan nilai karakter sebagai dimensi terdalam pendidikan yang membudayakan dan memberadabkan para pelaku pendidikan. Siswa yang menerima pelatihan keterampilan sosial atau penguatan pendidikan karakter lebih kecil kemungkinannya melakukan tindak pidana atau terlibat dalam perilaku kekerasan (Gunawan et al., 2020; Jhon et al., 2021).

Siswa SD UMP kelas 1 sampai dengan kelas 6 selain menerima kurikulum dari Kemendikbud juga kurikulum keislaman dan kemuhammadiyahan selama enam hari efektif. Selain itu mereka juga dilatih life skill serta senantiasa dimonitor perilaku mereka oleh guru kelas masing-masing. Penguatan pendidikan karakter diberikan kepada siswa bersamaan dengan pendidikan akademik selama di sekolah dan selalu dimonitor setiap hari aktivitas siswa di sekolah maupun di rumah oleh guru kelas dan orang tua.

SD UMP menitikberatkan tiga aspek nilai-nilai karakter yang wajib dimiliki dan diupayakan menjadi kebiasaan sehari-hari. Ketiga aspek tersebut adalah religius (ibadah), kemandirian dan sosial. Aspek ibadah mempunyai 12 indikator/aktivitas yang diperhatikan, yaitu: berwudhu dengan baik dan benar, melaksanakan sholat shubuh, dhuhur, ashar, maghrib dan isya', melaksanakan sholat dhuha, tahajjud/qiyamul lail serta sholat sunnah rowatib, 
tadarus al Quran, ziyadah (menambah hafalan), muroja'ah (mengulang hafalan), khusyu' dalam berdzikir serta rajin mengikuti kegiatan imtaq.

Aspek kemandirian meliputi 22 indikator, yaitu: bangun tidur sendiri, merapikan tempat tidur, menggosok gigi, mandi sendiri, memakai baju sendiri, makan sendiri, belajar, menyiapkan buku pelajaran sendiri, tidur sendiri, mengerjakan tugas/PR, datang ke sekolah tidak terlambat, mengucapkan salam, berjabat tangan dengan sopan, memakai seragam sesuai jadwal, mengikuti kegiatan belajar mengajar dengan baik, membawa perlengkapan belajar sesuai jadwal, melaksanakan tugas piket, menjaga kebersihan kelas, makan dengan tertib dan tidak tercecer, mengumpulkan tugas/PR, membuang sampah pada tempatnya serta izin pada guru. Adapun aspek sosial dipantau dalam 10 indikator, yaitu: bergaul dengan teman/tetangga, membantu orang tua, berperilaku sopan dan santun, bergaul dengan anggota keluarga, taat dan patuh kepada guru, berbicara dan berperilaku sopan, tidak bertengkar dengan teman, jujur, tanggap menolong orang lain serta ramah kepada teman.

Setiap hari baik di sekolah maupun di rumah, siswa SD UMP senantiasa dipantau perilaku/aktivitas yang membangun dan menguatkan karakter positif, terutama dalam aspek religius, kemandirian dan aspek sosial. Total indikator/aktivitas yang pantau setiap hari adalah 40 indikator. Untuk memudahkan pemantauan perilaku tersebut, SD UMP membuat buku penghubung kegiatan siswa dan wali murid.

Setiap hari buku penghubung kegiatan siswa dan wali murid diisi secara manual baik oleh siswa maupun guru kelas. Mereka memberi cek list $(\sqrt{ })$ pada aktivitas yang telah dilaksanakan oleh siswa di sekolah maupun di rumah. Selanjutnya guru kelas dan orang tua/wali murid akan mengkonfirmasi dan memvalidasi dengan cara membubuhkan paraf untuk keseluruhan aktivitas yang dilaksanakan pada setiap harinya.

Pengisian dan pemantauan buku penghubung kegiatan siswa dan wali murid dilakukan untuk setiap siswa setiap hari selama satu tahun ajaran. Pemantauan dilakukan oleh setiap guru kelas dan asisten. Setiap guru kelas di SD UMP rata-rata memantau 25-30 siswa. Sehingga setiap hari guru kelas dibantu asisten harus memantau dan membuat cek list sebanyak 10001200 aktivitas yang dilakukan oleh semua siswa di kelasnya setiap hari. Buku penghubung kegiatan siswa dan wali murid seperti pada Gambar 1.

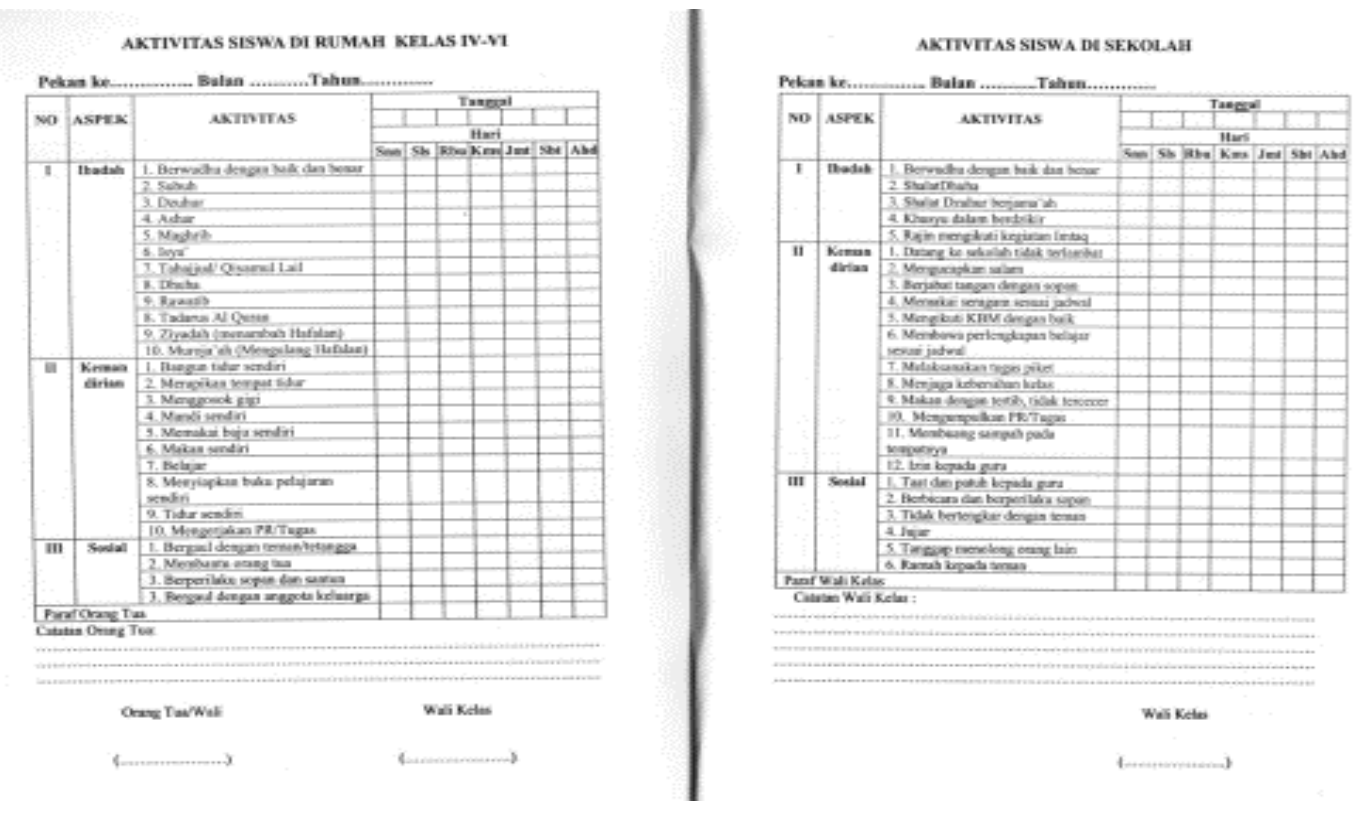

Gambar 1. Buku manual-pemantauan karakter siswa 
Pengisian dan pemantauan perilaku siswa dalam buku penghubung serta pembuatan laporan rekapitulasi pelaksanaan aktivitas setiap semester sangat menyita waktu guru kelas. Padahal tanggungjawab guru kelas selain memantau karakter siswa juga masih banyak yang lainnya. Sehingga dalam program penguatan karakter siswa, guru kelas baru dapat mengidentifikasi aktivitas/karakter mana saja yang belum dilaksanakan secara rutin setelah melakukan rekapitulasi pada akhir semester.

Model penguatan pendidikan karakter tersebut, juga menyebabkan siswa, orang tua dan guru hanya terfokus pada rutinitas pencatatan dan pelaporan atas pelaksanaan aktivitas/indikator karakter saja. Guru kelas belum dapat menitikberatkan proses evaluasi dan perbaikan karakter siswa sehingga seluruh aktivitas/indikator karakter tersebut secara rutin dilaksanakan karena telah menjadi kebiasaan baik. Padahal pendidikan karakter yang berhasil adalah ketika seseorang secara rutin aktivitas baik (beramal sholeh) dilakukan karena telah menjadi kebiasaan (habit).

Berdasarkan latar belakang tersebut, kegiatan pengabdian kepada masyarakat ini bermaksud memberikan penyuluhan, pengembangan, pelatihan dan pendampingan penggunaan teknologi informasi kindfull-digital character book. Kegiatan pengabdian pada masyarakat ini dilaksanakan di SD UMP. Tujuan kegiatan ini adalah a) mengenalkan kepada mitra atas penggunaan teknologi informasi untuk penguatan pendidikan karakter, b) mengembangkan aplikasi kindfull-digital character book sebagai instrumen penguatan pendidikan karakter, dan c) memberikan keterampilan penggunaan kindfull-digital character book sebagai solusi media pemantauan karakter siswa yang efektif dan efisien. Luaran utama atas solusi yang ditawarkan adalah diterapkannya teknologi tepat guna (aplikasi kindfulldigital character book) dalam penguatan pendidikan karakter.

\section{METODE PENERAPAN}

Sasaran pelaksanaan kegiatan ini adalah kepala sekolah, guru dan orang tua SD UMP dan SD Muhammadiyah di Kabupaten Banyumas. Jumlah peserta yang menjadi sasaran dalam kegiatan ini adalah sebanyak 60 orang. Hasil dari pelaksanaan kegiatan ini, diharapkan subyek dapat menyebarluaskan kepada guru maupun orang tua di sekolah lain. Penerapan kegiatan pengabdian ini dapat menjadi problem solving dalam penguatan pendidikan karakter.

Metode kegiatan yang dilakukan adalah pengenalan, pengembangan, pelatihan dan pendampingan penggunaan aplikasi kindfull-digital character book sebagai instrumen penguatan pendidikan karakter. Kegiatan dilakukan dan tiga tahap, yaitu: tahap persiapan, pelaksanaan kegiatan dan penutup. Secara terinci tahapan kegiatan ini disajikan pada Tabel 13.

Tabel 1. Tahap Persiapan

\begin{tabular}{|c|c|c|c|}
\hline Kegiatan & Tujuan & Peran Tim Pelaksana & Peran Mitra \\
\hline $\begin{array}{l}\text { Penguatan tim } \\
\text { pelaksana kegiatan }\end{array}$ & $\begin{array}{l}\text { Membuat struktur } \\
\text { organisasi dan } \\
\text { pembagian tugas }\end{array}$ & $\begin{array}{l}\text { Menyiapkan struktur } \\
\text { organisasi dan pembagian } \\
\text { tugas tim pelaksana } \\
\text { kegiatan PKM }\end{array}$ & $\begin{array}{l}\text { Menyiapkan tim pelaksana dan } \\
\text { pembagian tugasnya }\end{array}$ \\
\hline $\begin{array}{l}\text { Administrasi } \\
\text { kegiatan }\end{array}$ & $\begin{array}{l}\text { Menyiapkan } \\
\text { administrasi kegiatan } \\
\text { dan bukti pelaksanaan } \\
\text { kegiatan }\end{array}$ & $\begin{array}{l}\text { Menyiapkan jadwal } \\
\text { kegiatan, daftar hadir } \\
\text { peserta, berita acara } \\
\text { kegiatan, sertifikat bagi } \\
\text { pemateri dan peserta }\end{array}$ & $\begin{array}{l}\text { Menyiapkan tempat kegiatan, } \\
\text { daftar peserta (guru, siswa dan } \\
\text { orang tua), surat undangan } \\
\text { peserta }\end{array}$ \\
\hline
\end{tabular}




\begin{tabular}{llll}
\hline $\begin{array}{l}\text { Persiapan bahan } \\
\text { pelaksanaan } \\
\text { kegiatan }\end{array}$ & $\begin{array}{l}\text { Menyiapkan materi } \\
\text { sebagai bahan } \\
\text { presentasi bagi peserta }\end{array}$ & $\begin{array}{l}\text { Menyiapkan dan } \\
\text { menggandakan materi } \\
\text { presentasi } \\
\text { Menyiapkan soal pre-test } \\
\text { dan post-test }\end{array}$ & $\begin{array}{l}\text { Menyiapkan fasilitas seperti: } \\
\text { tempat pelaksanaan, LCD, dan } \\
\text { sarana prasarana lainnya }\end{array}$ \\
$\begin{array}{l}\text { Pembuatan bahan } \\
\text { evaluasi kegiatan }\end{array}$ & $\begin{array}{l}\text { Sebagai alat ukur } \\
\text { tingkat keberhasilan } \\
\text { kegiatan }\end{array}$ & $\begin{array}{l}\text { Menyiapkan kuesioner } \\
\text { kepuasan pengguna } \\
\text { aplikasi kindfull-digital } \\
\text { character book }\end{array}$ & \\
\hline
\end{tabular}

Tabel 1. menggambarkan proses persiapan pelatihan penggunaan aplikasi kindfull-digital character book. Pada tahap ini dilakukan beberapa langkah yang dilakukan bersama oleh tim pelaksana dan mitra secara harmonis. Kegiatan tersebut meliputi penguatan kolaborasi, administrasi, fasilitas dan pengembangan alat evaluasi.

Tabel 2. Tahap Pelaksanaan Kegiatan

\begin{tabular}{|c|c|c|c|}
\hline Kegiatan & Tujuan & Peran Tim Pelaksana & Peran Mitra \\
\hline Desain aplikasi & Sinkronisasi data dan fitur & $\begin{array}{l}\text { Mendesain aplikasi yang } \\
\text { sesuai dengan kebutuhan } \\
\text { pengguna }\end{array}$ & $\begin{array}{l}\text { Menyediakan data siswa, } \\
\text { orang tua, guru dan } \\
\text { indikator karakter. } \\
\text { Menyediakan form dan } \\
\text { laporan pemantauan } \\
\text { karakter }\end{array}$ \\
\hline Desain database & Sinkronisasi data dan fitur & $\begin{array}{l}\text { Mendesain sistem } \\
\text { database }\end{array}$ & $\begin{array}{l}\text { Menyediakan perangkat } \\
\text { keras dan admin sistem } \\
\text { informasi }\end{array}$ \\
\hline $\begin{array}{l}\text { Desain laporan } \\
\text { periodik dalam } \\
\text { aplikasi }\end{array}$ & Sinkronisasi data dan fitur & $\begin{array}{l}\text { Mendesain laporan } \\
\text { harian, mingguan dan } \\
\text { semester dalam aplikasi } \\
\text { penguatan pendidikan } \\
\text { karakter }\end{array}$ & $\begin{array}{l}\text { Menyediakan perangkat } \\
\text { keras dan admin sistem } \\
\text { informasi }\end{array}$ \\
\hline $\begin{array}{l}\text { Pelatihan dan } \\
\text { pendampingan } \\
\text { dengan admin } \\
\text { sistem informasi }\end{array}$ & $\begin{array}{l}\text { Melatih admin dalam } \\
\text { mengelola database sistem } \\
\text { informasi penguatan } \\
\text { pendidikan karakter }\end{array}$ & $\begin{array}{l}\text { Menyediakan perangkat } \\
\text { lunak, hosting, materi dan } \\
\text { tim pelatih }\end{array}$ & $\begin{array}{l}\text { Menyediakan perangkat } \\
\text { keras, jaringan internet } \\
\text { (wifi) dan admin sistem } \\
\text { informasi }\end{array}$ \\
\hline $\begin{array}{l}\text { Pelatihan dan } \\
\text { pendampingan } \\
\text { dengan guru kelas }\end{array}$ & $\begin{array}{l}\text { Melatih guru kelas } \\
\text { menggunakan aplikasi } \\
\text { kindfull-digital character } \\
\text { book }\end{array}$ & $\begin{array}{l}\text { Menyediakan aplikasi } \\
\text { kindfull-digital character } \\
\text { book, materi dan tim } \\
\text { pelatih }\end{array}$ & $\begin{array}{l}\text { Menyediakan } \\
\text { smartphone, jaringan } \\
\text { internet (wifi) dan guru } \\
\text { kelas }\end{array}$ \\
\hline $\begin{array}{l}\text { Pelatihan dan } \\
\text { pendampingan } \\
\text { dengan siswa dan } \\
\text { orang tua }\end{array}$ & $\begin{array}{l}\text { Melatih siswa dan orang tua } \\
\text { menggunakan aplikasi } \\
\text { kindfull-digital character } \\
\text { book }\end{array}$ & $\begin{array}{l}\text { Menyediakan aplikasi } \\
\text { kindfull-digital character } \\
\text { book, materi dan tim } \\
\text { pelatih }\end{array}$ & $\begin{array}{l}\text { Menyediakan } \\
\text { smartphone, jaringan } \\
\text { internet (wifi), siswa dan } \\
\text { orang tua }\end{array}$ \\
\hline $\begin{array}{l}\text { Pre-test dan Post- } \\
\text { test }\end{array}$ & $\begin{array}{l}\text { Mengetahui kemampuan } \\
\text { peserta pelatihan yang } \\
\text { berkaitan dengan materi }\end{array}$ & $\begin{array}{l}\text { Menyediakan soal pre- } \\
\text { test dan post test }\end{array}$ & $\begin{array}{l}\text { Memberikan jawaban pre- } \\
\text { test dan post test }\end{array}$ \\
\hline $\begin{array}{l}\text { Kuesioner } \\
\text { kesuksesan } \\
\text { penggunaan sistem } \\
\text { informasi }\end{array}$ & $\begin{array}{l}\text { Mengukur efektivitas } \\
\text { penggunaan aplikasi } \\
\text { kindfull-digital character } \\
\text { book }\end{array}$ & $\begin{array}{l}\text { Menyediakan instrumen } \\
\text { kuesioner mengenai } \\
\text { efektivitas penggunaan } \\
\text { aplikasi kindfull-digital } \\
\text { character book }\end{array}$ & $\begin{array}{l}\text { Memberikan tanggapan } \\
\text { atas kuesioner mengenai } \\
\text { efektivitas penggunaan } \\
\text { aplikasi kindfull-digital } \\
\text { character book }\end{array}$ \\
\hline
\end{tabular}

Tabel 2 menunjukkan proses pelaksanaan pelatihan pelatihan penggunaan aplikasi kindfulldigital character book. Pada tahap ini, dilakukan beberapa langkah yang mendukung keberhasilan penerapan aplikasi kindfull-digital character book di sekolah mitra. Dalam pelaksanaan kegiatan, melibatkan guru, orang tua dan siswa. 
Tabel 3. Tahap Penutup

\begin{tabular}{|c|c|c|c|}
\hline Kegiatan & Tujuan & Peran Tim Pelaksana & Peran Mitra \\
\hline Evaluasi kegiatan & $\begin{array}{l}\text { Mengetahui kinerja } \\
\text { kegiatan yang telah } \\
\text { dilakukan }\end{array}$ & $\begin{array}{l}\text { Melakukan evaluasi hasil pre- } \\
\text { test, post-test, hasil kuesioner } \\
\text { serta saran dan kritik dari } \\
\text { peserta }\end{array}$ & $\begin{array}{l}\text { Memberikan jawaban pre- } \\
\text { test, post-test, kuesioner serta } \\
\text { saran dan kritik }\end{array}$ \\
\hline $\begin{array}{l}\text { Pembuatan laporan } \\
\text { akhir, artikel } \\
\text { kegiatan }\end{array}$ & $\begin{array}{l}\text { Melaporkan } \\
\text { rangkaian } \\
\text { kegiatan yang telah } \\
\text { dilakukan }\end{array}$ & $\begin{array}{l}\text { Membuat laporan akhir dan } \\
\text { artikel kegiatan PKM } \\
\text { Mempublikasikan artikel } \\
\text { kegiatan } \\
\text { Membuat HaKI karya cipta } \\
\text { aplikasi kindfull-digital } \\
\text { character book }\end{array}$ & - \\
\hline
\end{tabular}

Tabel 3 menunjukkan proses evaluasi pelatihan penggunaan aplikasi kindfull-digital character book. Evaluasi dilakukan untuk mengukur tingkat keberhasilan kegiatan tersebut. Pada akhir kegiatan ini peserta dievaluasi mengenai pemahaman dan penguasaan mereka atas penggunaan aplikasi kindfull-digital character book sebagai instrumen penguatan pendidikan karakter. Evaluasi juga dilakukan atas efektivitas penggunaan aplikasi tersebut. Instrumen evaluasi yang digunakan adalah pre-test dan post-test serta kuesioner efektivitas penggunaan kindfull-digital character book sebagai aplikasi pemantauan dalam rangka penguatan pendidikan karakter. Kuesioner menggunakan indikator yang dikenalkan Davis (1989), yaitu persepsi kegunaan dan kemudahan dan penggunaan aplikasi.

\section{HASIL DAN KETERCAPAIAN SASARAN}

Tahap awal pelaksanaan kegiatan, tim pelaksana melakukan sinkronisasi aplikasi. Sinkronisasi dilakukan untuk menyesuaikan aplikasi kindfull-digital character book dengan kebutuhan sekolah dalam penguatan pendidikan karakter bagi siswanya. Aplikasi ini telah didesain dengan memberikan kemudahan, user friendly dan fleksibel sehingga dapat dengan mudah menyesuaikan kebutuhan sekolah. Sekolah lain juga dapat menggunakannya, karena dapat disesuaikan dengan prioritas pengembangan karakter di sekolah masing-masing. Pengembangan karakter sesuai dengan nilai utama karakter bangsa, yaitu religius, nasionalis, mandiri, gotong royong dan integritas (Perpres no.87/2017).

Aplikasi kindfull-digital character book menggunakan webservices, android dengan server. Aplikasi bisa melakukan request data ke webservices. Request diteruskan ke server. Setelah respons diberikan oleh server, data akan diubah dalam format JSON oleh webservices. Format tersebut dapat dibaca oleh aplikasi android.

Perangkat keras yang digunakan terdiri dari laptop yang memiliki komponen prosesor berupa Intel ${ }^{\circledR}$ Core ${ }^{\circledR}$ i7-7700HQ dengan kecepatan $2.80 \mathrm{GHz}$. Konfigurasi prosesor yaitu 4 core dan 8 logical processor, kartu grafis NVIDIA GeForce GTX 1050, RAM sebesar 8 GB RAM DDR4, dengan kapasitas hardisk sebesar 1 TB ditambah SSD sebesar 256 GB, dan layar beresolusi sebesar 1920 x 1080 px.

Perangkat lunak yang digunakan yaitu Microsoft Windows 10 Pro 64-bit. Bahasa pemrograman yang digunakan adalah XML untuk memanipulasi tampilan, dan Kotlin untuk melakukan operasi logika. Kemudian menggunakan IDE Android Studio 3.5 untuk menulis kode. Selama proses pengembangan, menggunakan perangkat dengan versi Android 9 (Pie). Implementasi fungsi yang dilakukan adalah fungsi login, halaman dashboard, halaman aktifitas yang perlu dikerjakan, aktivitas yang sudah dikerjakan, validasi aktifitas, dan rekap 
data aktivitas. Tampilan antar muka (user interface) aplikasi kindfull-digital character book disajikan pada Gambar 2.
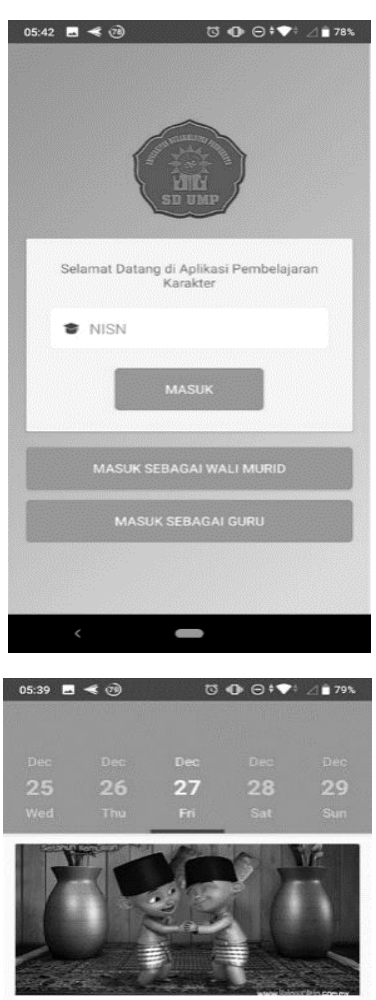

Sosial

Lengkapi Sosialmu

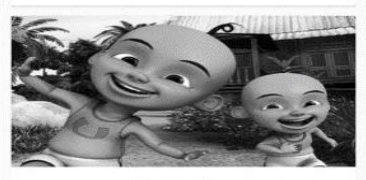

$\hookrightarrow$
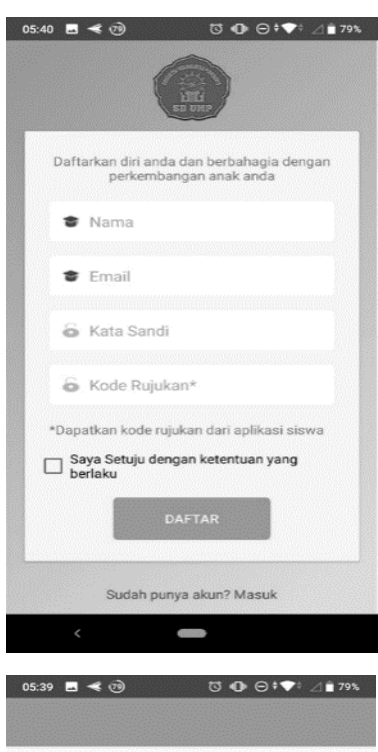

Sosial
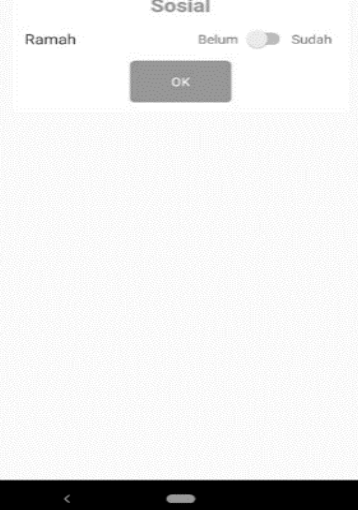

Fitriati et al.

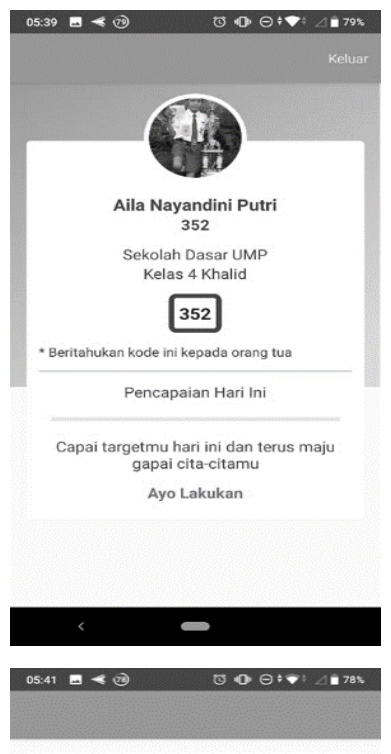

35

Gambar 2. User interface aplikasi kindfull-digital character book

Penggunaan aplikasi kindfull-digital character book dilakukan secara online oleh siswa, orang tua/wali, guru dan admin program. Aplikasi yang berbasis website dioperasikan oleh admin program di sekolah. Website ini digunakan untuk membuat database mengenai: sekolah, kelas, guru, siswa dan orang tua, indikator serta laporan pemantauan tiap siswa karakter yang dikembangkan sekolah.

Siswa menggunakan aplikasi ini dengan melakukan login sesuai NISN. Selanjutnya siswa mengisi secara self assessment atas aktivitas harian yang telah dilakukan. Aktivitas harian tersebut merupakan prioritas karakter yang telah ditentukan sekolah. Orang tua/wali dapat melakukan verifikasi setelah siswa melakukan self assessment. Ketika melakukan verifikasi, orang tua juga harus melakukan pendaftaran dengan mengisi nama, alamat email, password dan kode rujukan (yang akan menghubungkannya dengan siswa). Selanjutnya guru kelas akan melakukan validasi.

Aplikasi ini menggunakan self assessment, sehingga sangat menekankan pada kejujuran baik dari siswa, orang tua dan guru. Melalui buku saku karakter, peserta didik diberikan kepercayaan untuk melakukan penilaian terhadap diri sendiri, sebagai bentuk penanaman 
kejujuran pada peserta didik. Aplikasi ini juga menyediakan fitur verifikasi dari orang tua. Pembentukan karakter anak adalah kewajiban orang tua. Orang tua harus selalu memberi contoh dan mengingatkan anak untuk senantiasa berperilaku baik. Hal yang sama juga dilakukan oleh guru di sekolah. Sehingga orang tua dan guru harus bekerjasama memantau, mengevaluasi dan memperbaiki perilaku anak sehari-hari baik di rumah maupun di sekolah. Diharapkan perilaku baik siswa akan membentuk karakter/kebiasaan baik (habit) dalam kehidupan hingga akhir hayatnya.

Aplikasi kindfull-digital character book didesain tidak hanya untuk siswa SD. Sejak dari PAUD/TK, SD, SMP dan seterusnya mereka dapat menggunakan aplikasi ini untuk menguatkan pendidikan karakter mereka. Indikator perilaku baik yang akan dibiasakan dapat dilakukan secara bertahap sejak dini dan terus berkembang selama kehidupannya. Sehingga diharapkan pembentukan karakter ini bisa dimulai sejak usia dini dan terus-menerus dilakukan pembiasaan anak berperilaku baik sehingga terbentuk karakter yang baik.

Aplikasi dilengkapi fitur yang dapat diakses oleh user baik guru, orangtua dan siswa sesuai dengan kewenangannya. Penggunaan aplikasi dapat memudahkan guru kelas dan orang tua dalam mengakses dan memberikan informasi keadaan siswa. Aplikasi kindfull-digital character book berguna sebagai instrumen monitoring aktivitas pembinaan siswa dalam penguatan karakter. Penggunaan aplikasi memungkinkan kepala sekolah, guru, dan orangtua dapat mengakses informasi khususnya terkait karakter siswa dengan cepat, tepat, akurat, relevan dan lengkap (Fitriati et al., 2020).

Pelatihan dan workshop penggunaan aplikasi kindfull-digital character book dilakukan dengan melibatkan kepala sekolah, guru dan orang tua yang menjadi sasaran kegiatan. Materi yang diberikan dalam pelatihan dan workshop tersebut, antara lain: (1) Dukungan gerakan nasional revolusi mental melalui penguatan pendidikan karakter; (2) Penggunaan teknologi informasi dalam upaya penguatan pendidikan karakter; (3) Penggunaan aplikasi kindfulldigital character book berbasis website dan android; dan (4) Pendampingan penggunaan aplikasi tersebut sebagai instrumen penguatan pendidikan karakter.

Materi dukungan gerakan nasional revolusi mental melalui penguatan pendidikan karakter menjelaskan bahwa gerakan nasional revolusi mental melalui pendidikan nasional berfokus pada pembentukan kompetensi dan penguatan karakter. Menurut Ki Hajar Dewantara, pendidikan merupakan upaya untuk menumbuhkan budi pekerti (kekuatan batin, karakter), pikiran (intelek) dan fisik tubuh anak. Gerakan penguatan pendidikan karakter menempatkan nilai karakter sebagai dimensi terdalam pendidikan yang membudayakan dan memberadabkan para pelaku pendidikan. Ada lima nilai utama karakter bangsa, yaitu: religius, nasionalis, mandiri, gotong royong dan integritas. Salah satu manfaat gerakan tersebut adalah adanya penguatan karakter siswa dalam mempersiapkan daya saing siswa dengan kompetensi abad 21, yaitu: berpikir kritis, kreativitas, komunikasi, dan kolaborasi.

Materi penggunaan teknologi informasi dalam upaya penguatan pendidikan karakter memberikan pemahaman mengenai bagaimana menggunakan teknologi informasi untuk memudahkan pengguna. Teknologi tersebut menjadi salah satu instrumen pemantauan untuk penguatan pendidikan karakter.

Era revolusi industri 4.0 mencirikan penggunaan teknologi informasi berbasis big data, integrasi sistem, internet of things maupun otomatisasi. Hal ini jika tidak disikapi secara bijaksana maka akan terlibas dalam disrupsi teknologi. Sekolah, guru, siswa sebagai bagian dan pelaku dari lembaga pendidikan dapat memanfaatkan teknologi informasi untuk 
meningkatkan mutu pendidikannya termasuk dalam penguatan pendidikan karakter. Pada materi ini, guru dan orang tua diperkenalkan dengan teknologi informasi yang dapat menunjang pendidikan di sekolah, termasuk aplikasi kindfull-digital character book.

Penggunaan aplikasi kindfull-digital character book berbasis website dipraktekkan oleh admin program di sekolah. Aplikasi kindfull-digital character book berbasis website telah didesain bahwa setiap sekolah dapat membuat akun dan mengisi database yang diperlukan seperti data sekolah, kelas, guru, siswa maupun nilai karakter yang diprioritaskan masingmasing. Fitur-fitur yang disediakan di aplikasi tersebut sangat mudah dipahami dan dioperasikan. Pengisian data dapat menggunakan fasilitas impor data dari data excel yang telah dimiliki sekolah sehingga tidak perlu diinput satu per satu. Pengisian data harus dilakukan oleh admin program yang ditunjuk oleh sekolah (guru BK atau guru/tenaga kependidikan yang menguasai teknologi informasi). Aplikasi kindfull-digital character book juga berbasis android juga dipraktekkan langsung oleh peserta kegiatan. Pengguna dalam aplikasi tersebut adalah siswa, orang tua/wali murid dan guru.

Setelah pelatihan dan workshop, dilanjutkan dengan kegiatan pendampingan. Pendampingan atas penggunaan aplikasi kindfull-digital character book dilakukan dari pengisian data base sekolah, kelas, guru, siswa serta kategori dan indikator karakter yang menjadi prioritas sekolah. Selanjutnya juga dilakukan ujicoba penggunaan aplikasi tersebut oleh siswa, orang tua dan guru. Pendampingan juga dilakukan untuk pembuatan laporan rekapitulasi pelaksanaan karakter para siswanya.

Evaluasi atas pelaksanaan kegiatan PKM dilakukan dengan menyebarkan kuesioner. Evaluasi dilakukan untuk mengukur tingkat keberhasilan dari program yang ditawarkan, melalui evaluasi atas efektivitas implementasi aplikasi kindfull-digital character book. Evaluasi dilakukan dengan menggunakan kuesioner untuk mengukur tingkat kepuasan dari pengguna (guru, maupun admin program) atas penggunaan buku saku karakter digital tersebut.

Berdasarkan hasil evaluasi seluruh peserta kegiatan antusias dan merasa perlu menggunakan teknologi informasi sebagai instrumen pemantauan karakter siswa. Aplikasi kindfull-digital character book dapat menjadi alternatif instrumen tersebut. Mereka memiliki persepsi kegunaan yang tinggi atas pemanfaatan aplikasi tersebut. Menurut persepsi mereka, menggunakan aplikasi kindfull-digital character book memungkinkan pemantauan karakter menjadi lebih efektif dan efisien, lebih cepat serta lebih bisa berinteraksi dan bekerjasama antara siswa, orang tua dan guru. Pada awalnya, mereka belum merasakan kemudahannya, karena aplikasi tersebut merupakan teknologi baru. Dengan pelatihan, workshop dan pendampingan mereka dapat merasakan kemudahannya meskipun masih terdapat kendala. Kendala yang dialami mereka antara lain: beberapa smartphone tidak compatible dengan aplikasinya, smartphone harus digunakan bersama-sama dengan pembelajaran daring karena pandemi covid-19, kapasitas penyimpanan data smartphone kurang besar, sinyal internet tidak stabil dll.

Kegunaan dan kemudahan yang telah dirasakan pengguna mempengaruhi sikap positif pengguna. Pengguna tidak memberikan sikap resisten atas perubahan penggunaan teknologi. Selanjutnya sikap positif menumbuhkan minat dan penggunaan aktual aplikasi kindfull-digital character book. Hal ini sesuai dengan teori Technology Acceptance Model (TAM) (Davis, 1989) yang menjelaskan perilaku pengguna dalam penerimaan teknologi yang digunakan.

Perilaku menggunakan teknologi informasi diawali adanya persepsi mengenai kegunaan (perceived usefulness) dan kemudahan menggunakan (perceived ease of use) aplikasi 
teknologi informasi (Davis, 1989). Persepsi kegunaan merujuk pada kegunaan yang dapat dirasakan pengguna ketika mereka menggunakan aplikasi. Bagi guru, adanya peningkatan kinerja yang dapat secara cepat dan tepat membuat laporan rekapitulasi aktivitas siswa. Guru kelas juga tidak lagi disibukkan dengan teknis pelaporan, tetapi dapat lebih fokus dalam pembinaan karakter siswa mereka. Bagi orang tua, penggunaan aplikasi tersebut dapat menjadi bentuk keterlibatan penguatan pendidikan karakter siswa.

Persepsi kemudahan menggunakan merujuk pada keyakinan bahwa pengguna tidak repot dan tidak membutuhkan usaha yang besar ketika mereka menggunakan aplikasi. Guru, orang tua dan siswa dapat mengakses aplikasinya dimana saja dan kapan saja karena telah tersedia secara online. Berdasarkan hasil evaluasi, juga diketahui bahwa pengguna merasa mudah mempelajari dan mengoperasikan aplikasi kindfull-digital character book. Mereka merasa aplikasi tersebut sangat fleksibel karena dapat menyediakan kebutuhan mereka terkait dengan penguatan pendidikan karakter. Kemudahan yang disediakan aplikasi tersebut, menyebabkan mereka merasa cepat menjadi terampil menggunakannya. Mereka juga merasa mudah untuk berbagi informasi tentang perkembangan karakter siswa.

Persepsi kegunaan dan kemanfaatan mempengaruhi sikap (attitude) pengguna atas aplikasi/teknologi informasi. Selanjutnya sikap positif dapat memperkuat niat (intention) pengguna untuk menggunakannya. Niat tersebut akan menentukan apakah pengguna akan menggunakan (behavior) aplikasi tersebut dalam penguatan pendidikan karakter. Pengguna yang telah merasakan penggunaan aplikasi memberi manfaat dan nilai tambah, ia akan berniat untuk menggunakannya terlepas apakah aplikasi tersebut mudah atau tidak mudah digunakan (Dewi et al., 2018; Nelson, 2007).
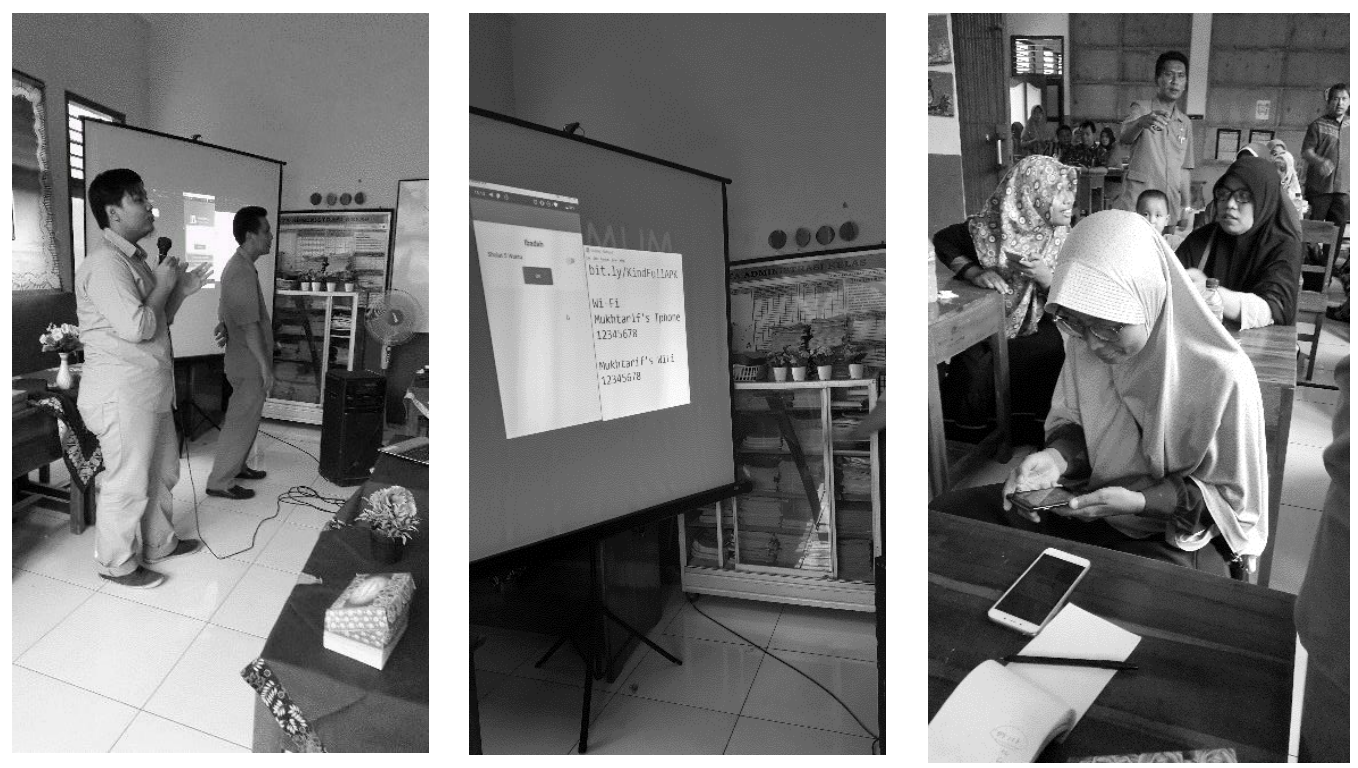

Gambar 3. Pelatihan Penggunaan Aplikasi kindfull-digital character book

Tingginya persepsi kegunaan dan kemudahan menyebabkan pengguna merasa puas dan percaya diri dalam menggunakan aplikasi kindfull-digital character book. Mereka juga percaya bahwa dengan menggunakan aplikasi akan menguatkan pendidikan karakter siswa. Tingkat ketercapaian kegiatan PKM disajikan pada Tabel 4. 
Tabel 4. Tingkat ketercapaian kegiatan PKM

\begin{tabular}{|c|c|c|c|}
\hline No & Indikator & $\begin{array}{l}\text { Sebelum } \\
\text { Kegiatan }\end{array}$ & Sesudah Kegiatan \\
\hline 1. & $\begin{array}{l}\text { Pemahaman penggunaan aplikasi kindfull- } \\
\text { character book sebagai software instrumen } \\
\text { pemantauan penguatan pendidikan karakter }\end{array}$ & na & $100 \%$ \\
\hline 2. & $\begin{array}{l}\text { Tumbuhnya sikap, minat dan penggunaan aplikasi } \\
\text { kindfull-character book }\end{array}$ & na & $100 \%$ \\
\hline 3. & $\begin{array}{l}\text { Efektivitas penggunaan aplikasi kindfull-character } \\
\text { book sebagai instrumen pemantauan penguatan } \\
\text { pendidikan karakter }\end{array}$ & na & $75 \%$ \\
\hline
\end{tabular}

Fitriati et al.

Berdasarkan hasil angket yang dibagikan setelah pelatihan, menunjukkan semua responden memahami dan berminat untuk menggunakan aplikasi kindfull-character book. Hal ini ditunjukkan dengan antusiasme mereka menggunakan gawai yang dimiliki untuk mengakses aplikasi dan mencoba fitur-fitur yang terdapat pada aplikasi tersebut. Sebagian besar responden menyatakan bahwa aplikasi tersebut lebih efektif dalam memantau aktivitas yang dilakukan oleh siswa ketika di rumah. Guru menyatakan bahwa mereka sangat terbantu dengan aplikasi tersebut untuk memantau perkembangan pendidikan karakter siswa secara berkala baik secara harian, minggu, bulanan bahkan bisa digunakan sebagai rapor pendamping.

\section{KESIMPULAN}

Aplikasi kindfull-digital character book merupakan salah satu instrumen penguatan pendidikan karakter. Aplikasi ini digunakan sebagai alat pemantau harian pelaksanaan karakter siswa. Aplikasi kindfull-digital character book berbasis website dan android. Aplikasi berbasis website digunakan oleh admin program sebagai pengelola database. Aplikasi berbasis android digunakan end user (guru, orang tua dan siswa) untuk mencatat, memverifikasi dan melaporkan aktivitas (karakter) yang telah dikerjakan siswa. Aplikasi telah didesain secara fleksibel dan user friendly. Sehingga pengguna dapat dengan mudah mempelajari dan mengoperasikannya. Aplikasi juga dapat disesuaikan dengan prioritas dan kebutuhan penguatan karakter yang dibutuhkan sekolah.

Aplikasi kindfull-digital character book memberikan alternatif solusi bagi sekolah dalam melakukan penguatan pendidikan karakter siswa. Penggunaan aplikasi tersebut memerlukan kejujuran siswa, kerjasama orang tua dan sekolah dalam upaya penguatan pendidikan karakter. Karena sesungguhnya pendidikan termasuk pendidikan karakter siswa merupakan kewajiban orang tua. Pendidikan akan berhasil jika terjalin kerjasama yang solid antara orang tua dengan pihak sekolah. Secara ekonomis, aplikasi ini dapat digunakan secara berulang, dengan menambahkan indikator karakter yang diinginkan.

Berdasarkan hasil evaluasi, diketahui bahwa pengguna telah merasakan kegunaan dan kemudahan menggunakan aplikasi. Pengguna merasa puas dan memiliki sikap positif atas aplikasi tersebut. Sikap ini akan menumbuhkan minat dan penggunaan aktual aplikasi kindfulldigital character book.

\section{UCAPAN TERIMA KASIH}

Ucapan terimakasih kami sampaikan kepada Deputi Bidang Riset dan Pengembangan Kemenristek/BRIN yang mendanai kegiatan PKM ini dengan nomor kontrak 
104/SP2H/PPM/DRPM/2020, tanggal 16 Maret 2020. Ucapan terimakasih juga kami sampaikan kepada SD/MI Muhammadiyah Kabupaten Banyumas yang telah berpartisipasi aktif dalam kegiatan pengabdian ini.

\section{Daftar Pustaka}

1. Agboola, A., \& Tsai, K. C. (2012). Bring Character Education into Classroom. European Journal of Educational Research, 1(2), 163-170. https://files.eric.ed.gov/fulltext/EJ1086349.pdf

2. Davis, F. 1989. Perceived Usefulness, Perceived Ease of Use and User Acceptance of Information Technology. MIS Quarterly, 13(3), 319-40. https://doi.org/10.2307/249008

3. Dewi, I. G. A. A. O., Dewi, I. G. A. A. P., Kustina, K. T., \& Prena, G. D. (2018). Culture of tri hita karana on ease of use perception and use of accounting information system. International Journal of Social Sciences and Humanities, 2(2), 77-86. https://pdfs.semanticscholar.org/9367/a87b364f67b627d0c296f9d48619c783788e.pdf

4. Fitriati, A., Tubastuvi, N., Pratama, B.C., and Anggoro, S. (2020). Study of Delone-Mclean information system success model: the relationship between system quality and information quality. Journal of Theoretical and Applied Information Technology, 98(03), 477-487. http://www.jatit.org/volumes/Vo198 No3/11Vol98No3.pdf

5. Gunawan, I., Rusdarti, R., \& Ahmadi, F. (2020). Implementation of Character Education for Elementary Students. Journal of Primary Education, 9(2), 168-175. https://journal.unnes.ac.id/sju/index.php/jpe/article/view/36646

6. Izzati, U. A., Bachri, B. S., Sahid, M., \& Indriani, D. E. (2019). Character education: Gender differences in moral knowing, moral feeling, and moral action in elementary schools in Indonesia. Journal for the Education of Gifted Young Scientists, 7(3), 547-556. https://dergipark.org.tr/en/download/article-file/806119

7. Jhon, W., Zubaidah, E., \& Mustadi, A. (2021). Challenges in the implementation of character education in elementary school: experience from Indonesia. Ilkogretim Online, 20(1), 13511363. http://dx.doi.org/10.17051/ilkonline.2021.01.130

8. Marini, A. (2018). Implementation of character building at elementary schools: Cases of Indonesia. In Proceeding International Conference on University and Intellectual Culture, 1(1), 60-71). http://seminars.unj.ac.id/icuic/wp-content/uploads/2018/08/7.-Implementation-ofCharacter-Building-at-Elementary-Schools-Cases-of-Indonesia-by-Arita-Marini-UniversitasNegeri-Jakarta.pdf

9. Nelson, R. R. (2007). IT Project Management: Infamous Failures, Classic Mistakes, and Best Practices. MIS Quarterly Executive, 6(2), 67-78. http://www2.commerce.virginia.edu/CMIT/Research/MISQE\%206-07.pdf

10. Peraturan Presiden Republik Indonesia Nomor 87 Tahun 2017 tentang Penguatan Pendidikan Karakter

11. Saputri, N. C., Rokhman, F., \& Zulaeha, I. (2019). Writing Essay with Conservation Contained in Elementary School to Build Positive Character Education About Environment. Journal of Primary Education, 8(3), 281-290. https://journal.unnes.ac.id/sju/index.php/jpe/article/view/27514

12. Suyitno, H., Zaenuri, Sugiharti, E., Suyitno, A., \& Baba, T. (2019). Integration of Character Valuesin Teaching-Learning Process of Mathematics at Elementary School of Japan. International Journal of Instruction, 12(3), 781-794. https://doi.org/10.29333/iji.2019.12347a 